\title{
Using Pseudomonas spp. for Integrated Biological Control
}

\author{
Virginia O. Stockwell and James P. Stack
}

First author: Department of Botany and Plant Pathology, Oregon State University, Corvallis 97331-2902; and second author: Plant Pathology Department, Kansas State University, Manhattan 66506-5502.

\begin{abstract}
Stockwell, V. O., and Stack, J. P. 2007. Using Pseudomonas spp. for integrated biological control. Phytopathology 97:244-249.

Pseudomonas spp. have been studied for decades as model organisms for biological control of plant disease. Currently, there are three commercial formulations of pseudomonads registered with the U.S. Environmental Protection Agency for plant disease suppression, Bio-Save 10 LP, Bio-Save $11 \mathrm{LP}$, and BlightBan A506. Bio-Save $10 \mathrm{LP}$ and Bio-Save 11 LP, products of Jet Harvest Solutions, Longwood, FL, contain Pseudomonas syringae strains ESC-10 and ESC-11, respectively. These products are applied in packinghouses to prevent postharvest fungal diseases dur-

produced by NuFarm Americas, Burr Ridge, IL, contains $P$. fluorescens strain A506. BlightBan A506 is applied primarily to pear and apple trees during bloom to suppress the bacterial disease fire blight. Combining BlightBan A506 with the antibiotic streptomycin improves control of fire blight, even in areas with streptomycin-resistant populations of the pathogen. BlightBan A506 also may reduce fruit russet and mild frost injury. These biocontrol products consisting of Pseudomonas spp. provide moderate to excellent efficacy against multiple production constraints, are relatively easy to apply, and they can be integrated with conventional products for disease control. These characteristics will contribute to the adoption of these products by growers and packinghouses.
\end{abstract} ing storage of citrus, pome, stone fruits, and potatoes. BlightBan A506,
In the 1990 s, several pseudomonads were approved as registered biopesticides with the U.S. Environmental Protection Agency (USEPA). These strains are listed on the USEPA biopesticide website and described in a review by Fravel (4). Pseudomonas chlororaphis strain 63-28 was commercialized as the product AtEze, by EcoSoil Systems in California. AtEze was applied as a soil drench in greenhouse containers for the suppression of soilborne pathogens such as Pythium spp., Rhizoctonia solani, and Fusarium oxysporum. P. aureofaciens strain Tx1 also was commercialized by EcoSoil Systems as Spot-less Biofungicide. This product was intended for application through golf course irrigation systems to control dollar spot, anthracnose, pink snow mold, and diseases caused by Pythium spp. Although no longer commercially available, these two products remain registered biopesticides with the USEPA.

In 1992, Plant Health Technologies, Latham, CA, registered three pseudomonads in their product called FrostBan: P. fluorescens strain 1629RS, P. syringae 742RS, and P. fluorescens strain A506. Only $P$. fluorescens strain A506 is commercially available and is now sold as BlightBan A506 by NuFarm Americas, Burr Ridge, IL.

Two other pseudomonads, $P$. syringae strain ESC-10 and $P$. syringae strain ESC-11, were registered in 1995 and EcoScience Corporation developed these strains in the Bio-Save product line for the suppression of postharvest diseases. These products are now distributed by Jet Harvest Solutions in Florida.

Bio-Save Products. Bio-Save $10 \mathrm{LP}$ and Bio-Save $11 \mathrm{LP}$ are used for the suppression of postharvest diseases. ESC-10 is a strain of $P$. syringae that was isolated from apple by scientists at EcoScience Corporation and is the active ingredient in the

Corresponding author: V. O. Stockwell

E-mail address: stockwev@science.oregonstate.edu

DOI: 10.1094/PHYTO-97-2-0244

(C) 2007 The American Phytopathological Society commercial products called Bio-Save $10 \mathrm{LP}$, Bio-Save 100, and Bio-Save 1000. Bio-Save $10 \mathrm{LP}$ is effective for the control of postharvest diseases of citrus, stone fruits, apple, and potatoes. ESC-11 is a strain of $P$. syringae isolated from apple leaves by Janisiewicz and Machi (12) and is the active ingredient in the commercial products Bio-Save $11 \mathrm{LP}$ and Bio-Save 110. Strain ESC-11 was originally called $P$. syringae strain L-59-66; the name was changed by EcoScience $(6,10,12)$. Bio-Save $11 \mathrm{LP}$ is effective for controlling postharvest diseases of pears and potatoes.

ESC-10 and ESC-11 are assigned to the species syringae without a pathovar designation; they are considered saprophytic strains. In early tests, strain ESC-11 did not cause hypersensitive response when infiltrated into tobacco leaves, and did not cause lesion formation on pear seedlings, or ooze formation in an immature pear fruit assay (12). Smilanick et al. (33) confirmed that ESC-11 did not cause hypersensitive response in tobacco leaves, but reported that ESC-10 was positive in this assay. Using carbohydrate utilization assays and GC-fatty acid analyses, they determined that the strains were distinct and that ESC-10 was more closely related to a pathogenic strain of $P$. syringae pv. syringae that causes citrus blast (33). Strains ESC-10 and ESC-11 did not cause necrosis or form spreading lesions on inoculated citrus fruit, but at high inoculum doses the strains caused small lesions on the fruit of Persian lime. Both strains also caused small lesions on leaves of several citrus cultivars. Nonetheless, in every assay, the damage caused was inconsequential and the strains were less virulent than the pathogenic strain causing citrus blast. They concluded that these antagonists did not pose a significant threat to citrus fruit, shoots, or foliage (33).

Millions of dollars are lost annually to postharvest diseases of fruits and vegetables. Annual losses are estimated at 5 to $20 \%$ in the United States and $50 \%$ of stored crops in developing countries (11). Few chemicals are registered for application to consumables and resistance of decay pathogens to those chemicals has become an increasing problem. The need for alternative control measures 
led to the development of the Bio-Save product line with ESC-10 and ESC-11. A comprehensive review of the biological control of postharvest diseases of fruit was published recently by Janisiewicz and Korsten (11).

Biological control is an attractive management strategy for those postharvest diseases where the pathogen infects during or after harvest. Many postharvest diseases of pome and citrus fruits are caused by pathogens that require a wounded plant surface to gain ingress and initiate infection. Fruit contacts with equipment, shipping vessels, and other fruits during harvest, handling, and transport can lead to bruises, puncture wounds, stem pulls, and abrasions on fruit surfaces that can be infection courts for pathogens. Furthermore, a high percentage of the fruit will be placed into storage within a regulated environment. Temperature, relative humidity, and atmospheric composition can all be controlled very accurately. This combination of timing of infection and a regulated environment makes postharvest systems near ideal for the introduction of a biological control agent to prevent decay. It is possible in postharvest systems to add a biocontrol agent to the plant site in need of protection, at a concentration necessary for efficacy, and regulate the environmental conditions to maintain protection.

The postharvest handling system of fruit prior to storage is amenable to application of biopesticides. The bacteria in the BioSave products are insensitive to several materials used during postharvest handling, like diphenylamine used for scald protection and the fungicides imazalil and thiabendazole used for decay prevention. There are many variations of how fruit are handled prior to packing; in general, fruit are cleaned, sorted to remove damaged or rotted fruits, and then packed into storage containers. Often, fruit are cleaned by floating in dump tanks or by in-line sprayers. After cleaning, fruit are rinsed with clean water or treated with fungicides. Most fruit are waxed before sorting or storage and fungicides are often combined with the waxes. These treatments reduce the magnitude of postharvest decay, unless fungicide-resistant pathogens are prevalent. Biopesticide products like Bio-Save are applied to citrus and pome fruit on the packline before waxing. Although Bio-Save products can be applied to pome fruits (e.g., pear and apple) and stone fruits as a drench, over-head spray is recommended for optimum efficacy due to the wide variation in commercial drench protocols and water quality management. For potatoes, Bio-Save is applied as an overhead spray prior to storage.

Effective formulation of biocontrol agents is a persistent concern. Bio-Save products were initially formulated as wettable powders or frozen pellets (11). Preliminary efficacy trials with biocontrol agents often are performed with bacterial cells harvested from solidified culture media; cells in a formulated product may not behave similarly $(4,37)$. Janisiewicz and Jeffers (10) found that cells of ESC-11 in a wettable powder formulation provided the same population dynamics and control efficacy as fresh cell preparations on apple fruit. The Bio-Save products were commercialized as frozen concentrates containing $3 \times 10^{11} \mathrm{CFU} / \mathrm{g}$ packaged in containers resembling milk cartons. Currently, the product is formulated as lyophilized cells at a concentration of $9 \times 10^{10} \mathrm{CFU} / \mathrm{g}$ and stored frozen. The packages are lighter and easier to handle than frozen concentrates during shipping and storage. In a packinghouse, the product is suspended in water to achieve final concentrations of $3 \times 10^{11} \mathrm{CFU} / \mathrm{ml}$. Applied at these rates to wounded fruit, $P$. syringae is recovered at approximately $6 \times 10^{6} \mathrm{CFU}$ per wound, which is adequate for protection (J. P. Stack, unpublished data). Colonization of fruits by these antagonists is specific to wound sites. Bull et al. (1) demonstrated that ESC-10 and ESC-11 establish similar populations in wounds of citrus fruit. On unwounded fruit surfaces, the populations of these bacteria decline to below detection within 1 to 2 weeks after application. In commercial trials, the populations on unwounded fruit surfaces declined to below detection limits in hours as a result of the waxing and drying process (J. P. Stack, unpublished data).

The mechanism of control is proposed to be due to competition for sites and nutrients in wounds. ESC-10 and ESC-11 must be applied to wounds before or shortly after the introduction of the pathogen for optimum efficacy. If the bacteria are applied 24 or more hours after inoculation, disease control is less effective (32, 34). As with most biocontrol bacteria, large populations $\left(>10^{6} \mathrm{CFU}\right.$ per wound) are required for efficacy $(1,12)$, and metabolically active populations of the antagonist are needed to achieve disease suppression. Treatment of wounds with ESC-11 followed by treatment with streptomycin, which killed the bacterium, resulted in loss of control of blue mold on apple (14). In related research, the addition of $80 \mathrm{mM} \mathrm{L}$-asparagine or L-proline to the preparation of ESC-11 significantly improved biological control of blue mold of apple $(7,8,14)$. It has been proposed that the increased disease control was due to enhanced growth of the antagonist with the amino acid supplement. Whereas competition is accepted as the mechanism of control of decay fungi by Bio-Save products, Bull et al. (2) found that ESC-10 and ESC-11 produced the lipodepsinonapeptide syringomycin $\mathrm{E}$ in culture under certain conditions at quantities sufficient to inhibit growth of Penicillium digitatum in vitro. Furthermore, addition of purified syringomycin E to wounds controlled green mold to levels similar to application of the strains. However, in wounded fruit treated with ESC-10 or ESC-11, Bull et al. (2) could not demonstrate that syringomycin E is produced at sufficient concentrations to inhibit pathogen growth. Syringomycin E or other antibiotics have not been detected in fruit treated with ESC-10 or ESC-11. No inhibitory compounds are produced by ESC-10 or ESC-11 during culture in the media used for commercial production of Bio-Save products (J. P. Stack, unpublished data).

In further work to determine the mechanisms of action, gacA mutants of strain ESC-10 that were deficient in production of syringomycin $\mathrm{E}$ and an extracellular protease were compared with the wild-type strain for efficacy against green mold (C. A. Bull and J. L. Smilanick, personal communication). While wound populations of the gacA mutants and the wild-type strains were not significantly different, biocontrol efficacy of the mutant strains was reduced by approximately $50 \%$ compared with the wild-type ESC-10 strain. A protease-competent, syringomycin Edeficient mutant of ESC-11 was generated by marker exchange mutagenesis; the syringomycin E-deficient mutant was equal to the wild-type ESC-11 strain in efficacy for control against green mold (C. A. Bull and J. L. Smilanick, personal communication). Although it is possible that syringomycin E contributes to suppression of decay pathogens at some level, antibiosis does not appear to be the primary mechanism of action.

Decay control efficacy in pathogen-inoculated trials on citrus and pome fruits by ESC-10 and ESC-11 is summarized in Tables 1 and 2. On citrus (Table 1), ESC-10 or Bio-Save 10 LP outperformed ESC-11 for control of green mold and blue mold. Control of decay fungi by ESC-10 on lemons was better than control on orange (Table 1). ESC-11 is primarily used for control of decay on pear and apple, although ESC-10 also provides significant control of rots on apple (Table 2). Host-specific effects are observed for control of postharvest disease on pear cultivars by ESC-11 (Table 2). Excellent control of gray mold and blue mold was seen with ESC-11 on Anjou pear stored at ambient or cold temperatures, whereas significantly less disease control was obtained on Bosc pear with ESC-11.

Bio-Save products also have been tested on crops other than those in Tables 1 and 2. ESC-10 was effective against brown rot of peach caused by Monilinia fructicola, but did not reduce Rhizopus rot of peach $(27,48)$. Bio-Save $10 \mathrm{LP}$ is registered for use on citrus (lemon, orange, and grapefruit) for control of $P$. digitatum, $P$. italicum, and Geotrichum candidum; on cherries for control of P. expansium and Botrytis cinerea; on apples and 
pears for control of $P$. expansium, B. cinerea, and Mucor piriformis; and on potatoes for control of F. sambucinum and Helminthosporium solani. Bio-Save $11 \mathrm{LP}$ is registered for use on sweet potato for control of Rhizopus stolonifer and for the same decay pathogens on apple, pear, and potato as Bio-Save 10 LP.

In several laboratory and commercial trials, disease control by Bio-Save products was shown to be independent of fungicide resistance status of the pathogen (J. P. Stack, S. N. Jeffers, and L. Yourman, unpublished data). This was true for decay prevention on lemons with populations of $P$. digitatum and $P$. italicum resistant to either imazalil or thiabendazole and decay prevention on apples with populations of $P$. expansum resistant to thiabendazole. On Bosc pear, ESC-11 provided similar levels of control of thiabendazole-sensitive and -resistant isolates of Penicillium expansum (Table 2). In commercial packinghouse trials, treatment of Bosc pear with Bio-Save $11 \mathrm{LP}$ combined with a low dose of thiabendazole $(100 \mathrm{ppm})$ provided similar control for several decays as did treatment with only thiabendazole at the recommended rate $(569 \mathrm{ppm})$. In commercial packhouses with fungicide-resistant pathogen populations, the application of BioSave provided approximately a five-to-one economic return (J. P. Stack, unpublished data).

Janisiewicz and Korsten (11) provided an excellent summary of strategies to improve biological control of postharvest diseases of fruits and the incorporation of antagonists with fungicide applications. Pressure infiltration of apple with calcium chloride followed by treatment with ESC-11 provided greater control of blue mold than either treatment applied individually (9). Heat treatment or cold treatment of apple fruit before inoculation reduced the number and size of lesions caused by $P$. expansum (20). The application of pseudomonads before or after heat treatment provided residual control of decay. Combining ESC-10 with sodium carbonate or sodium bicarbonate overcame the shortcomings of single treatments for control of green mold of citrus (Table 1) (34). They suggested that the biocontrol agent tolerated residual carbonates in wounds and provided protection against re-infection. Finally, combining ESC-11 with the yeast Sporobolomyces roseus improved control of blue mold of apple compared with that of single strain treatments (8).

Steady adoption of Bio-Save products for the control of postharvest decays has occurred since their introduction in the mid1990s. Currently, approximately 1 million cartons of citrus, 4 to 8 million cartons of pear and apple, approximately 8 million lugs of cherry, and 3 million sacks of potato are treated with Bio-Save annually.

BlightBan A506. BlightBan A506 is a registered biopesticide for the suppression of frost damage on cherry, almond, peach, tomato, potato, strawberry, and pome fruits. The primary commer-

TABLE 1. Relative percent control of postharvest decays on citrus fruits

\begin{tabular}{|c|c|c|c|c|c|c|c|}
\hline \multirow[b]{2}{*}{ Decay } & \multirow[b]{2}{*}{ Host } & \multicolumn{5}{|c|}{ Treatment } & \multirow[b]{2}{*}{ Reference } \\
\hline & & ESC-10 & ESC-11 & Imazalil & Sodium carbonate & $\begin{array}{l}\text { ESC-10 and } \\
\text { sodium carbonate }\end{array}$ & \\
\hline $\begin{array}{l}\text { Blue mold (Penicillium italicum) and } \\
\text { green mold (Penicillium digitatum) }\end{array}$ & $\begin{array}{l}\text { Lemon } \\
\text { Orange }\end{array}$ & $\begin{array}{l}88^{\mathrm{a}} \\
59\end{array}$ & $\begin{array}{l}\mathrm{NT}^{\mathrm{b}} \\
\mathrm{NT}\end{array}$ & $\begin{array}{l}\text { NT } \\
\text { NT }\end{array}$ & $\begin{array}{l}\text { NT } \\
\text { NT }\end{array}$ & $\begin{array}{l}\text { NT } \\
\text { NT }\end{array}$ & $\begin{array}{l}1 \\
1\end{array}$ \\
\hline Green mold (Penicillium digitatum) & $\begin{array}{l}\text { Lemon } \\
\text { Lemon } \\
\text { Lemon } \\
\text { Orange }\end{array}$ & $\begin{array}{c}88(80 \text { to } 99)^{\mathrm{c}} \\
95 \text { to } 99 \\
90 \\
50(40 \text { to } 59)\end{array}$ & $\begin{array}{c}60(29 \text { to } 82) \\
70 \text { to } 98 \\
39 \\
\text { NT }\end{array}$ & $\begin{array}{c}98 \\
\text { NT } \\
98 \\
\text { NT }\end{array}$ & $\begin{array}{c}\text { NT } \\
\text { NT } \\
\text { NT } \\
73(64 \text { to } 84)\end{array}$ & $\begin{array}{c}\text { NT } \\
\text { NT } \\
\text { NT } \\
83(78 \text { to } 89)\end{array}$ & $\begin{array}{r}1 \\
2 \\
34 \\
35\end{array}$ \\
\hline
\end{tabular}

a Mean reduction in incidence of decay compared with control.

${ }^{\mathrm{b}}$ Not tested.

${ }^{c}$ Values in parentheses represent the range in decay control among trials.

TABLE 2. Relative percent control of postharvest decays on pome fruits

\begin{tabular}{|c|c|c|c|c|c|c|c|}
\hline \multirow[b]{3}{*}{ Decay } & \multirow[b]{3}{*}{ Host } & \multicolumn{5}{|c|}{ Treatment } & \multirow[b]{3}{*}{ Reference } \\
\hline & & & Cold storage & Ambient & & & \\
\hline & & ESC-10 & ESC-11 & ESC-11 & $\mathrm{TBZ}^{\mathrm{a}}$ & and TBZ & \\
\hline & Bartlett pear & NT & 86 & 100 & NT & NT & 13 \\
\hline & Bosc pear & NT & 15 & 78 & NT & NT & 13 \\
\hline $\begin{array}{l}\text { Blue mold (Penicillium expansum) and } \\
\text { gray mold (Botrytis cinerea) }\end{array}$ & & & & & & & \\
\hline \multirow[t]{7}{*}{ Blue mold (Penicillium expansum) } & Anjou pear & NT & 93 & 84 & NT & NT & 13 \\
\hline & Bartlett pear & NT & 69 & 46 & NT & NT & 13 \\
\hline & Bosc pear & NT & 41 & 40 & NT & NT & 13 \\
\hline & Empire apple & 57 to 66 & NT & NT & 100 & NT & 48 \\
\hline & Delicious apple & 58 to 73 & NT & NT & 98 & NT & 48 \\
\hline & Pink Lady apple & NT & 100 & 100 & NT & NT & 14 \\
\hline & Ace Spur Delicious apple & NT & 100 & 72 & NT & NT & 14 \\
\hline $\begin{array}{l}\text { Total decay in packinghouse (blue mold, gray } \\
\text { mold, Bull's eye rot, Side, and other rots) }\end{array}$ & Bosc pear & NT & NT & NT & $77^{\mathrm{d}}$ & $59^{\mathrm{d}}$ & 40 \\
\hline
\end{tabular}

a Thiabendazole. Applied between 569 to 1,000 ppm a.i. or 100 ppm when used with ESC-11.

${ }^{\mathrm{b}}$ Not tested.

${ }^{\mathrm{c}}$ Mean reduction in incidence of decay compared with control.

d Significant reduction in decay compared to control, but no significant difference between treatments. 
cial use of BlightBan A506 is for the suppression of fire blight, which is reflected in the name change of the product from FrostBan B to BlightBan A506. It was estimated that 7,000 to 10,000 pounds of the active ingredient of BlightBan A506 was applied annually to pear and apple orchards in the United States in the 1990s and up to $30 \%$ of the orchard acreage in California alone was treated with three applications of A506 (U.S. Department of Agriculture-National Agricultural Statistics Service).

Fire blight is a devastating disease of pear and apple flowers and shoots caused by the bacterial pathogen Erwinia amylovora. The pathogen colonizes the stigmas of flowers as an epiphyte, and then migrates to the nectary where it invades host tissues through the natural openings of the nectar secretion cells called nectarthodes $(44,46)$. The pathogen causes wilt and necrosis of infected floral tissues and branches. Disease management focuses on preventing epiphytic growth of the pathogen prior to infection, as no chemical controls are effective after invasion of tissues (30). Organic and conventional growers may use copper or the antibiotics oxytetracycline (registered only for pear) or streptomycin to suppress the epiphytic growth phase of the pathogen on flowers. Copper and the bacteriostatic antibiotic oxytetracycline are only partially effective for disease control (30). The bactericidal antibiotic streptomycin has been the most effective chemical for control of fire blight. Unfortunately, the pathogen has developed resistance to streptomycin in the western states and Michigan (24-26). Streptomycin resistance coupled with increased plantings of apple cultivars and rootstocks sensitive to fire blight have resulted in several epidemics of fire blight in the western states and Michigan and millions of dollars of damage to orchards. These factors increased the need for alternative disease control measures such as biological control.

The active ingredient in BlightBan A506 is the epiphytic bacterium $P$. fluorescens strain A506 (A506). It was isolated from a pear tree in California by S. Lindow at University of California, Berkeley (21). In orchard tests, A506 reduced fruit russet by 25 to $40 \%$ and reduced frost injury of pear by at least $50 \%(21-24)$. In large-scale trials reliant on indigenous pathogen populations, it was also noted that the incidence of fire blight on A506-treated trees was reduced by 60 to $80 \%$ (21-24). From these studies, A506 emerged as a potential biocontrol agent for the suppression of fruit russet, frost injury, and fire blight of pear.

The mechanism of control of fire blight by A506 was elucidated in studies by Wilson and Lindow (45) conducted on flowers on potted pear trees. They demonstrated that A506 is an excellent colonist of floral tissues, achieving populations in excess of $10^{6} \mathrm{CFU}$ per flower on stigmas and $10^{5} \mathrm{CFU}$ per flower on nectaries. E. amylovora achieves similar populations on stigmas as an epiphyte, but is a superior colonist of nectaries, developing populations of $10^{7} \mathrm{CFU}$ as it invades these tissues. When E. amylovora was co-inoculated with A506, the growth of the pathogen was not influenced by the growth of A506. When E. amylovora was inoculated $72 \mathrm{~h}$ after treatment with A506, pathogen growth was suppressed reaching only $10^{3} \mathrm{CFU}$ per stigma which is unlikely to result in successful infection of floral tissues. Because A506 was not known to produce an antibiotic and large A506 populations were required for suppression of the pathogen, Wilson and Lindow concluded that the primary mechanism of control of fire blight was competitive exclusion. This information was essential for the development of biologically based management strategies for fire blight.

The commercial product BlightBan A506 is composed of lyophilized cells of A506 at a concentration of $1 \times 10^{10}$ to $1 \times$ $10^{11} \mathrm{CFU} / \mathrm{g}$. The material is diluted with water in orchard sprayers to a concentration of $1 \times 10^{7}$ to $1 \times 10^{8} \mathrm{CFU} / \mathrm{ml}$. Multiple applications of BlightBanA506 are recommended during the bloom period to ensure exclusion of the pathogen on newly opened flowers. The product label recommends applications at early bloom (20\% bloom), full bloom, and post-petal fall or secondary bloom to every row or every other row of trees in an orchard. The alternate row application method presumes that insect activity and abiotic factors will spread the biocontrol agent to nonsprayed trees in the orchard $(15-19,23,41)$. In early studies, E. amylovora was detected in orchards in California at full bloom, but not during early bloom (41). Early bloom sprays of A506 are recommended to establish large populations of the biocontrol agent prior to the arrival of the pathogen. Furthermore, pome fruit flowers are receptive to colonization by bacteria for about 4 days after opening $(23,42)$. If A506 becomes established on a flower, then populations persist for several weeks during fruit development. Delayed applications of A506 may result in less efficient colonization of older flowers by the biocontrol agent. Even if the biocontrol agent is applied during early bloom, Nuclo et al. (28) noted that establishment and colonization may fail. In subsequent trials, Johnson et al. $(18,19)$ found that temperature and rainfall are important factors mediating successful establishment and growth of biocontrol agents on flowers; mean daily orchard temperatures above $12^{\circ} \mathrm{C}$ led to successful establishment by A506, whereas at lower temperatures the bacteria failed to thrive. They developed a decision aid for growers to determine optimal application times based on bloom stage and forecasted weather (19).

As mentioned previously, competitive exclusion was determined to be the mechanism of disease control by which A506 provides control of fire blight under conditions of light to moderate disease pressure (21-24). Disease control by A506 diminishes with greater disease pressure, such as pathogen-inoculated field trials $(15,16,31)$. Methods to enhance disease control by A506 under conditions with greater disease pressure are under development. For example, it was discovered that exogenous iron induces A506 to produce a potent antibiotic with activity against $E$. amylovora (41). Available iron on flowers is present in concentrations too low for the induction of antibiotic production by A506 (40). Combining A506 with the iron chelate FeEDDHA at $3 \mathrm{mM}$ provided the bacterium with exogenous iron (40) and significantly improved disease control. In pathogen-inoculated field trials, A506 reduced the incidence of fire blight by an average of $22 \%$, whereas the combination of A506 plus FeEDDHA reduced the disease incidence by $52 \%$ (V. O. Stockwell, J. E. Loper, and K. B. Johnson, unpublished data). The improved control of fire blight obtained with the co-application of A506 and FeEDDHA is similar to levels obtained with other antagonists that produce antibiotics $(31,38)$. The practice of combining A506 with FeEDDHA has been adopted by some pome fruit growers in Oregon. The discovery of the iron-regulated antibiotic provides another method to improve control of fire blight by BlightBan A506.

Control of fire blight by BlightBan A506 can be improved further by integration with application of antibiotics. A506 can be applied with streptomycin because the bacterium is resistant to the antibiotic (36). In large-scale orchard trials with indigenous streptomycin-resistant and -sensitive strains of the pathogen, the combination of A506 with antibiotics significantly improved disease control compared with each treatment individually (22). Lindow et al. (22) suggested that A506 improved control with antibiotics by reducing the growth of E. amylovora on flowers after partial eradication with antibiotics, which lose activity on flowers after a few days (43). It was suggested that the application of the biocontrol agent may replace some applications of antibiotics (22), but as pointed out by Epstein and Bassein (3), this has not been realized. In a survey of California pear growers, it was determined that growers who used BlightBan A506 applied the same number of antibiotic sprays as growers that did not use BlightBan A506. This may be due to limited research on how the thresholds for disease warning systems or other decision aids for antibiotic applications may be modified to account for use of biological control agents. Furthermore, whereas streptomycin can be tank-mixed with A506, oxytetracycline at 200 ppm a.i. can be deleterious to the growth of A506 (36). Thus, oxytetracycline 
should be applied several days after application of A506, thereby allowing the bacterium to establish large populations (36). In recent orchard trials, application of BlightBan A506 followed by a single application of oxytetracycline at late bloom provided greater control of fire blight than two oxytetracycline sprays (V. O. Stockwell, K. B. Johnson, and J. E. Loper, unpublished data). Inclusion of iron with A506 followed by oxytetracycline improved disease control further. Whereas BlightBan A506 is well established in pome fruit production markets in the western United States, these modifications for use of the product may improve disease control for growers.

\section{CHALLENGES AND PROSPECTS}

What are the limitations for the use of pseudomonads for biological control? There are several challenges in the advancement of a biocontrol agent from a scientific model to a viable commercial product. Among the nontechnical challenges is the registration process with regulatory agencies, such as the federal USEPA and agencies within each state. Tier I environmental safety tests are described in the biopesticide section of the USEPA website. The tests can be an expensive investment, often requiring funds from the private sector to cover the costs (5). Promising biological control strains identified as Burkholderia cepacia (P. cepacia) or $P$. aeruginosa face insurmountable obstacles to registration. These species encompass plant-associated strains as well as strains that are opportunistic pathogens of humans (29). Until definitive tests are developed to distinguish strains capable of causing disease in humans from those that are harmless environmental isolates, it is unlikely that strains of these species will be registered.

Fravel (4) cites formulation technology of microbial agents as an area requiring additional research to enhance the efficacy of biological disease control strategies. Non-spore-forming bacteria, such as the pseudomonads, are sensitive to stresses potentially encountered during formulation and prolonged storage. High-titer products are required for the rapid introduction and establishment of sufficient populations to affect biological control. Cells in a high-titer product can rapidly lose viability during storage, especially if mishandled during shipping or distribution. Currently, formulated products contain lyophilized cells of pseudomonads that must be stored in freezers. A high-titer biopolymer formulation of A506 demonstrated good shelf-life at refrigerated temperatures and excellent colonization of flowers (35). This type of formulation may be more economical to produce than lyophilized cells, but is unlikely to be commercialized. The economical production of high-titer formulations of pseudomonads that are shelfstable at room temperature is a research priority.

The production and distribution of formulated products can impact usage and adoption. Epstein and Bassein (3) illustrate this point with the usage of BlightBan A506 in California during the late 1990s. When availability was limited due to reduced production, a corresponding decrease in use of BlightBan A506 was documented. Fortunately growers used the product again after the product line was purchased by NuFarm Americas and production and distribution stabilized.

Finally, the biological control agent must have a sustainable market niche and the registrant must make sure that the infrastructure is utilized effectively to teach growers and postharvest handlers how to best use the product. Demonstrations by university extension personnel, researchers, industry, commodity groups, and crop consultants can improve adoption, illustrate reasonable expectations of the product, point out potential incompatibility with other agricultural inputs, and decrease the incidence of failures to control disease through misuse of biopesticides.

Factors contributing to success of Bio-Save products and BlightBan A506. In addition to meeting the challenges outlined above, there are several factors that have lead to the successful commercialization of Bio-Save and BlightBan A506. Both products are applied easily to potential infection sites using existing sprayers or packinghouse line equipment. The diseases controlled by these products have discrete infection sites. For postharvest diseases, wounds created during harvest and handling need to be protected during storage under controlled conditions. For fire blight, the stigmas of pear and apple flowers need to be protected from colonization by the pathogen during the bloom period which extends for only a few weeks. Each product is used to control an array of pathogens. For Bio-Save products, several postharvest decay fungi can be controlled on citrus, pome fruits, stone fruits, and tubers. BlightBan A506 provides significant control of fire blight caused by E. amylovora, russet caused by IAA-producing bacteria, and frost injury due to ice-nucleation active bacteria.

Another factor contributing to the success of these products is that they target pathogens for which few effective alternatives are available. Fungicides for control of postharvest decay are limited because the chemicals are applied directly to consumables. For the existing fungicides, the development of resistance has limited their effectiveness. For fire blight, the emergence of streptomycin resistance in E. amylovora has left growers with few options for effective disease control. These biological control agents also may be of value in managing the development of fungicide or antibiotic resistance in the target pathogens. A final factor contributing to the success of these products is that they are approved for use in organic production systems. The approval of these products for organic agriculture opens up additional niche markets for these biological control agents. We anticipate that other promising strains of pseudomonads targeted to niche markets where few alternatives exist for disease control will be commercialized successfully in the future.

\section{LITERATURE CITED}

1. Bull, C. T., Stack, J. P., and Smilanick, J. L. 1997. Pseudomonas syringae strains ESC-10 and ESC-11 survive in wounds on citrus and control green and blue molds of citrus. Biol. Control 8:81-88.

2. Bull, C. T., Wadsworth, M. L., Sorensen, K. N., Takemoto, J. Y., Austin, R. K., and Smilanick, J. L. 1998. Syringomycin E produced by biological control agents controls green mold on lemons. Biol. Control 12:89-95.

3. Epstein, L., and Bassein, S. 2003. Patterns of pesticide use in California and the implications for strategies for reduction of pesticides. Annu. Rev. Phytopathol. 41:351-375.

4. Fravel, D. R. 2005. Commercialization and implementation of biocontrol. Annu. Rev. Phytopathol. 43:337-359.

5. Harman, G. E. 2000. Myths and dogmas of biocontrol: Changes in perceptions derived from research on Trichoderma harzianum T-22. Plant Dis. 84:377-393.

6. Janisiewicz, W. J. 1987. Postharvest biological control of blue mold on apples. Phytopathology 77:481-485.

7. Janisiewicz, W. J. 1994. Enhancement of biocontrol of blue mold with the nutrient analog 2-deoxy-D-glucose on apples and pears. Appl. Environ. Microbiol. 60:2671-2676.

8. Janisiewicz, W. J., and Bors, B. 1995. Development of a microbial community of bacterial and yeast antagonists to control wound-invading postharvest pathogen of fruits. Appl. Environ. Microbiol. 61:3261-3267.

9. Janisiewicz, W. J., Conway, W. S., Glenn, D. M., and Sams, C. E. 1998. Integrating biological control and calcium treatment for controlling postharvest decay of apple. HortScience 33:105-109.

10. Janisiewicz, W. J., and Jeffers, S. N. 1997. Efficacy of commercial formulation of two biofungicides for control of blue mold and gray mold of apples in cold storage. Crop Prot.16:629-633.

11. Janisiewicz, W. J., and Korsten, L. 2002. Biological control of postharvest diseases of fruits. Annu. Rev. Phytopathol. 40:411-441.

12. Janisiewicz, W. J., and Machi, A. 1992. Control of storage rots on various pear cultivars with a saprophytic strain of Pseudomonas syringae. Plant Dis. 76:555-560.

13. Janisiewicz, W. J., and Peterson, D. L. 2004. Susceptibility of the stem pull area of mechanically harvested apples to blue mold decay and its control with a biocontrol agent. Plant Dis. 88:662-664.

14. Janisiewicz, W. J., Usall, J., and Bors, B. 1992. Nutritional enhancement of biocontrol of blue mold on apples. Phytopathology 82:1364-1370.

15. Johnson, K. B., and Stockwell, V. O. 1998. Management of fire blight: A case study in microbial ecology. Annu. Rev. Phytopathol. 36:227-248. 
16. Johnson, K. B., and Stockwell, V. O. 2000. Biological control. Pages 319337 in: Fire Blight: The Disease and Its Causative Agent, Erwinia amylovora. J. Vanneste, ed. CAB International, Wallingford, U.K.

17. Johnson, K. B., Stockwell, V. O., Burgett, D. M., Sugar, D., and Loper, J. E. 1993. Dispersal of Erwinia amylovora and Pseudomonas fluorescens by honey bees from hives to apple and pear blossoms. Phytopathology 83:478-484.

18. Johnson, K. B., Stockwell, V. O., and Sawyer, T. L. 2004. Adaptation of fire blight forecasting to optimize the use of biological controls. Plant Dis. 88:41-48.

19. Johnson, K. B., Stockwell, V. O., Sawyer, T. L., and Sugar, D. 2000. Assessment of environmental factors influencing growth and spread of Pantoea agglomerans on and among blossoms of pear and apple. Phytopathology 90:1285-1294.

20. Leverentz, B., Janisiewicz, W. J., Conway, W. S., Saftner, R. A., Fuchs, Y., Sams, C. E., and Camp, M. J. 2000. Combining yeasts or a bacterial biocontrol agent and heat treatment to reduce postharvest decay of 'Gala' apples. Postharvest Biol. Tech. 21:87-94.

21. Lindow, S. E. 1985. Integrated control and role of antibiosis in biological control of fire blight and frost injury. Pages 83-115 in: Biological Control on the Phylloplane. C. E. Windels and S. E. Lindow, eds. The American Phytopathological Society, St. Paul, MN.

22. Lindow, S. E., McGourty, G., and Elkins, R. 1996. Interactions of antibiotics with Pseudomonas fluorescens strain A506 in the control of fire blight and frost injury to pear. Phytopathology 86:841-848.

23. Lindow, S. E., and Suslow, T. V. 2003. Temporal dynamics of the biocontrol agent Pseudomonas fluorescens strain A506 in flowers in inoculated pear trees. Phytopathology 93:727-737.

24. Loper, J. E., Henkels, M. D., Roberts, R. G., Grove, G. G., Willet, M. J., and Smith, T. J. 1991. Evaluation of streptomycin, oxytetracycline, and copper resistance of Erwinia amylovora isolated from pear orchards in Washington state. Plant Dis. 75:287-290.

25. McManus, P. S., Stockwell, V. O., Sundin, G. W., and Jones, A. L. 2002. Antibiotic use in plant agriculture. Annu. Rev. Phytopathol. 40:443-465.

26. Moller, W. J., Schroth, M. N., and Thomson, S. V. 1981. The scenario of fire blight and streptomycin resistance. Plant Dis. 65:563-568.

27. Northover, J., and Zhou, T. 2002. Control of rhizopus rot of peaches with postharvest treatments of tebuconazole, fludioxonil, and Pseudomonas syringae. Can. J. Plant Pathol. 24:144-153.

28. Nuclo, R. L., Johnson, K. B., Stockwell, V. O., and Sugar, D. 1998. Secondary colonization of pear blossoms by two bacterial antagonists of the fire blight pathogen. Plant Dis. 82:661-668.

29. Parke, J. L., and Gurian-Sherman, D. 2001. Diversity of the Burkholderia cepacia complex and implications for risk assessment of biological control strains. Annu. Rev. Phytopathol. 39:225-258.

30. Psallidas, P. G., and Tsiantos, J. 2000. Chemical control of fire blight. Pages 199-234 in: Fire Blight: The Disease and Its Causative Agent, Erwinia amylovora. J. Vanneste, ed. CAB International, Wallingford, U.K

31. Pusey, P. L. 2002. Biological control agents for fire blight of apple compared under conditions limiting natural dispersal. Plant Dis. 86:639-644.
32. Smilanick, J. L., and Denis-Arrue, R. 1992. Control of green mold of lemons with Pseudomonas species. Plant Dis. 76:481-485.

33. Smilanick, J. L., Gouin-Behe, C. C., Margosan, D. A., Bull, C. T., and Mackey, B. E. 1996. Virulence on citrus of Pseudomonas syringae strains that control postharvest green mold of citrus fruit. Plant Dis. 80:11231128.

34. Smilanick, J. L., Margosan, D. A., Mlikota, F., Usall, J., and Michael, I. F. 1999. Control of citrus green mold by carbonate and bicarbonate salts and the influence of commercial postharvest practices on their efficacy. Plant Dis. 83:139-145.

35. Stockwell, V. O., Johnson, K. B., and Johnson, V. W. 2006. Colonization of flowers by Pseudomonas fluorescens A506 formulated in a biopolymer gel. Acta Hortic. 704:293-299.

36. Stockwell, V. O., Johnson, K. B., and Loper, J. E. 1996. Compatibility of bacterial antagonists of Erwinia amylovora with antibiotics used to control fire blight. Phytopathology 86:834-840.

37. Stockwell, V. O., Johnson, K. B., and Loper, J. E. 1998. Establishment of bacterial antagonists of Erwinia amylovora on pear and apple blossoms as influence by inoculum preparation. Phytopathology 88:506-513.

38. Stockwell, V. O., Johnson, K. B., Sugar, D., and Loper, J. E. 2002. Antibiosis contributes to biological control of fire blight by Pantoea agglomerans strain Eh252 in orchards. Phytopathology 92:1202-1209.

39. Sugar, D., and Spotts, R. A. 1999. Control of postharvest decay in pear by four laboratory-grown yeasts and two registered biocontrol products. Plant Dis. 83:155-158.

40. Temple, T. N., Stockwell, V. O., Loper, J. E., and Johnson, K. B. 2004. Bioavailability of iron to Pseudomonas fluorescens A506 on flowers of pear and apple. Phytopathology 94:1286-1294.

41. Thomson, S. V. 1986. The role of the stigma in fire blight infections. Phytopathology 76:476-482.

42. Thomson, S. V., and Gouk, S. C. 2003. Influence of age of apple flowers on growth of Erwinia amylovora and biological control agents. Plant Dis. $87: 502-509$.

43. Vanneste, J. L. 1996. Honey bees and epiphytic bacteria to control fire blight, a bacterial disease of apple and pear. Biocontrol News Inform. $17: 67 \mathrm{~N}-78 \mathrm{~N}$.

44. Wilson, M., Epton, H. A. S., and Sigee, D. C. 1989. Erwinia amylovora infection of hawthorn blossom: II. The stigma. J. Phytopathol. 127:15-28.

45. Wilson, M., and Lindow, S. E. 1993. Interactions between the biological control agent Pseudomonas fluorescens A506 and Erwinia amylovora in pear blossoms. Phytopathology 83:117-123.

46. Wilson, M., Sigee, D. C., and Epton, H. A. S. 1990. Erwinia amylovora infection of hawthorn blossom: III. The nectary. J. Phytopathol. 128:6274.

47. Zhou, T., Chu, C.-L., Liu, W. T., and Schaneider, K. E. 2001. Postharvest control of blue mold and gray mold on apples using isolates of Pseudomonas syringae. Can. J. Plant Pathol. 23:246-252.

48. Zhou, T., Northover, J., and Schaneider, K. E. 1999. Biological control of postharvest diseases of peach with phyllosphere isolates of Pseudomonas syringae. Can. J. Plant Pathol. 21:375-381. 